\begin{tabular}{|c|c|c|c|}
\hline$\because$ & a 1886.0 & $d \mathrm{I} 886,0$ & Ep. \\
\hline$g$ & $\begin{array}{r}\mathrm{I}^{\mathrm{h}} 33^{\mathrm{m}} 35^{\mathrm{s}} \cdot 49 \\
35 \cdot 33\end{array}$ & $\begin{array}{r}+39^{\circ} \circ^{\prime} 34.0 \\
34.3\end{array}$ & $\begin{array}{r}1886 \text { IX. I } 9 \\
\text { X. } 4\end{array}$ \\
\hline$h$ & $\begin{array}{r}575.70 \\
59.69\end{array}$ & $\begin{array}{r}+362156.5 \\
56.6\end{array}$ & $\begin{array}{r}1886 \text { IX. } 19 \\
\text { X. } 4\end{array}$ \\
\hline 2 & $\begin{array}{lrr}\text { I } 46 & 27.31 \\
& & 27.15\end{array}$ & $\begin{array}{r}+40 \quad 59 \cdot 3 \\
591\end{array}$ & $\begin{array}{r}1886 \text { IX. } 19 \\
\text { X. } 4\end{array}$ \\
\hline
\end{tabular}

Pulkowa 188 i Mai 20.

\begin{tabular}{|c|c|c|c|}
\hline$*$ & $\alpha \quad 1886.0$ & $\delta 1886.0$ & Ep. \\
\hline$k$ & $1^{\mathrm{h}} 47^{\mathrm{m}} 53^{\mathrm{s}}$. 10 & $+39^{\circ} 23^{\prime} 14^{\prime \prime} 7$ & 1 $886 X .27$ \\
\hline$l$ & $\begin{array}{lll}2 & 25 & 29.99 \\
& & 30.20\end{array}$ & $\begin{array}{rr}+5148 & 17.0 \\
& 17.2\end{array}$ & $\begin{array}{r}1886 \text { X. } 4 \\
\text { XI. } 25\end{array}$ \\
\hline$m$ & $\begin{array}{lll}242 & 5^{6.73} \\
& & 56.70\end{array}$ & $\begin{array}{rl}+4749 & 0.3 \\
& 0.0\end{array}$ & $\begin{array}{r}1886 \mathrm{X} .27 \\
\mathrm{XI} .25\end{array}$ \\
\hline$n$ & $\begin{array}{lll}3 & 2 \mathrm{I} & 0.23\end{array}$ & +394626.1 & $\begin{array}{l}1886 \mathrm{X} \cdot 4 \\
\text { Romberg. }\end{array}$ \\
\hline
\end{tabular}

\title{
Cordoba Observations of the Great Southern Comet 1887 I.
}

I send you herewith the extreme range of observations of this object that the poor skies permitted me to make. As announced by telegram, it was first seen in the evening of Jan. $18^{\text {th }}$, but the weather did not permit of obtaining even approximate determinations of position lefore the $21^{\text {st }}$. The telegram ought to have reached you early on the morning of the $\mathbf{2 2}^{\mathrm{d}}$, if there had been no delay in its transmission, ${ }^{*}$ ) and the announcement that the comet would become very bright was the best that the phrase-code permitted; and, indeed, closely enough described its appearance.

To the naked eye, and in the opera glass there was presented the singular phenomenon of an apparently detached cometary tail, beginning abruptly, as it seemed, with a width of from $15^{\prime}$ to $20^{\prime}$, and without discernible nucleus or source of light. In other respects, its appearance was exactly the same, even in the quality of its light, as that of the great comet of 1880 - a bright, straight, narrow tail over $40^{\circ}$ in length, shining with a silvery - white light. Substitute in the comet of 1880 , for the nebular nucleus of a little more than $I^{\prime}$ in diameter another which had been vaporized to nearly thirty times its diameter, and an exact representation of this object will be obtained.

Under these conditions, it was evident that consistent positions could not be obtained, but after trying various methods of approximation to fix the center of this indefinable vapor, I adopted the plan of following the axis of the tail as far as it was visible in the finder, and then guiding

Note

Jan. 21. The appearance of the comet is precisely the same as the one observed here in 1880 . It has a long, straight and narrow tail, inclined to the vertical at about $10^{\circ}$. Searched carefully for a nucleus but could find nothing even approaching one, the comet seeming to end indefinitely - lose itself. The star GC. 29273 occupied a central position in the axis of the comet, at $8^{\mathrm{h}} 43^{\mathrm{m}}$. The tail extended over $25^{\circ}$ degrees, beginning with the star GC. 29273 and ending just beyond $a$ Tucanae. Comet about $5^{\circ}$ above the horizon.

Jan. 22. Same general appearance as last night, but somewhat brighter. No nucleus or condensation of any kind found after protracted search. Begins with the star GC. 29623 and extends in straight line to the smaller cloud. the telescope through the attenuated matter, approximately $30^{\prime}$ in diameter, to its extreme anterior limit, beyond which nothing of a nebulous character could be distinguished. I hoped in this way to obtain nearly consistent determinations of the same place upon the cometary axis, and the accompanying places give its position from night to night as well as its illusory nature permitted.

These places, and my notes made at the time, are the same as those already sent to the Astronomical Journal, but of which. I have, as yet, heard nothing.* : As they were matde in the hour immediately preceding the regular Durchmusterung observations of the night, possibly they might have been fuller with nore time at my disposal, but I have nothing to modify in consequence of the statements of the other observers. If there had been a nucleus hidden at the extremity or brightest part of the tail, its brilliancy must have been such as to render the comet visible again after the moon had passed, whereas it faded first at the head. My conviction is that the comet passed so close to the sun that the nucleus was reduced to a thin vapor, and as the resemblance to the comet of 1880 was very striking, I have thought that it might be a return of that body; but no combination of these positions will give similar elements, and the identity can only be proved by another appearance. It is, however, not to be identified with the great comet of $\mathrm{I} 882$, in my opinion, for that body differed in many respects from the comet of 1880 .

The densest part of the tail seemed to be about $40^{5}$ following the star $\mathrm{GC} .29663$, where it was approximately $20^{\prime}$ wide. No distinctive point could be found between these two limits. Tail, narrow and clearly outlined, could be traced $40^{\circ}$ or more.

Jan. 24. Again no distinctive point to be found; observing as before, found $\mathrm{ZC} .{ }^{2} 3^{1}$ at the beginning, and located the densest part of the tail at $22^{\mathrm{h}} 9^{\mathrm{m}} 8^{\mathrm{s}}-48^{\circ} 55^{\prime}$. About $4 \mathrm{I}^{\circ}$ long.

Jan. 25. Comet fading rapidly - very difficult to fix upon the beginning, but finally decided upon GC. $3090 \mathrm{r}$.

Jan. 27 . Comet much fainter, and almost impossible to distinguish in the telescope. Rough place GC. 31895 . The observation is very doubtful.

*) Das Telegramm ist erst Januar 24 Nachmittags hier eingegangen, vgl. A. N. 2769. Kr.

*) Dieselben sind inzwischen veröffentlicht Astr. Journ. Nr. $156 . \mathrm{Kr}$. 


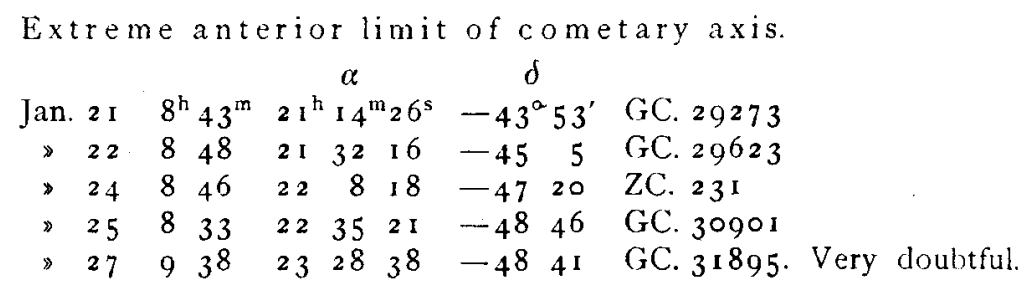

For the 'Tail.

Jan. $207^{\text {h }}$ to $8^{\text {h }}$, closely following $\theta$ Indi, extending from the horizon, about $15^{\circ}$, dimly visible in twilight and haze.

- $218^{\mathrm{h}} 50^{\mathrm{m}}$, extends from star to $\delta$ Tucanae in s.prec. side, limit beyond $a$ Tucanae; n. foll. side from star to intersection of $22^{\mathrm{h}}$ at $60^{\circ}$; limit about 2 ? beyond $\delta$ Tucanae.

- $228^{\mathrm{h}} 50^{\mathrm{m}}$, s. pr. side, a straight line from star to $\xi$ Tucanae; $\mathrm{n}$. foll. side, a straight line from star to $\lambda$ Tucanae; limit the nubecula minor.

- $248^{\mathrm{h}} 50^{\mathrm{m}}$, s. pr. side, a straight line from star to $\delta$ Hydri; n. foll. side, a straight line from star to UA. 46 Hydri; limit $2^{\circ}$ beyond

» $258^{\mathrm{h}} 5 \mathrm{0}^{\mathrm{m}}$, s. pr. border, straight from star to $\beta$ Reticuli; $\mathrm{n}$. foll. border, straight from star to $x$ Reticuli; limit $2^{\circ}$ beyond.

Cordoba 1887 July 4.

Fohn H. Thoine.

\section{Ueber den Ringnebel in der Leyer.}

Eine briefliche Mittheilung des Herrn E. von Gothard über die photographische Entdeckung eines »vielleicht ringförmigen Kerns" in der Mitte des Ringnebels der Leyer, woriuber er dann auch in den A. N. 2749 berichtete, veranlasste mich, da ich mich ebenfalls mit dem studium der Astrophotographie beschäftige, mit besonderem Interesse an einigen schönen Abenden gegen Ende September und Anfang October 1886 mit dem grossen Refractor dieses Object näher $z \mathrm{u}$ untersuchen, ob eine Veränderung eingetreten sei. Ich hätte dieselbe insofern ziemlich leicht- constatiren können. als ich mich im September 1885 mit der Anfertigung einer möglichst naturgetreuen Zeichnung dieses Nebels sammt den in und zunächst um den Nebel liegenden Sternen beschäftigt hatte. Es war mir aber unmöglich in Vergleich zu dieser Zeichnung eine Veränderung zu erkennen. Das Innere des Ringnebels erschien bei schwacher Vergrösserung wie von einem schwachen Lichtschleier überdeckt; bei stärkerer Vergrösserung jedoch erkennt man in diesem Schleier verschiedene Intensiaäten des Lichts, so dass das Innere ein schwach flockiges Ansehen bekommt. Südwestlich bis nahezu westlich vom Centrum des Nebels, ungefähr in der Mitte zwischen Centrum und innerem Rand des Nebelrings, ist eine hellere Lichtflocke stets recht gut $z u$ erkennen. Im östlichen Theile der inneren Ringfläche, nahe am Nebelrande sah ich zum wiederholten Male drei schwache Sternchen sowie an verschiedenen Stellen des Nebelrings selbst wiederholt feine Lichtpünktchen aufblitzen.

Ein Sternchen in der Nähe des Centrums war aber nicht zu sehen, was auch von Prof. Vogel in Potsdam, sowie durch photographische Aufnahmen der Gebrüder Henry in Paris bestätigt wurde (A. N. 2754).

Am 25 . Juli d. J. besuchte uns Prof. Young aus Princeton und wir sahen uns bei dieser Gelegenheit einige Objecte mit dem grossen Refractor an. Die Luft war leidlich gut,

Sternwarte Wien 1887 Juli 28. doch liess sie noch manches zu wünschen übrig. Als wir das Fernrohr auf den Ringnebel richteten, war ich erstaunt, auf den ersten Blick fast in der Mitte der inneren Ringfläche, etwas nordwestlich vom Centrum, ein kleines Sternchen zu sehen, gerade so, wie es sich auf der Gothard' schen Photographie zeigt, wovon uns ein Diapositiv freundlichst zugesandt wurde, nur ist es verhältnissmässig schwächer als es die Photographie zeigt.

Am 26. Juli habe ich das Sternchen, obwohl der Himmel nicht besonders rein war, auch wiederholt, aber nicht so gut wie Tages zuvor, gesehen. Wir haben es hier somit mit einem veränderlichen Sternchen $z u$ thun, welches sicherlich einige Aufmerksamkeit verdient. Wenn es zur Zeit, als v. Gothard dén Nebel photographirt hat, nicht etwa besonders hell gewesen ist, so kann seine Abbildung auf der photographischen Platte, weil einige andere schwache Sternchen in der Umgebung auf der Photographie nicht abgebildet sind, nur dadurch erklärt werden, dass es besonders reich an actinischem Licht ist.

Für die Veränderlichkeit dieses Sternchens, über dessen Sichtbarkeit zuerst Hahn im Berliner Jahrbuche von 1803 berichtet hat, sprechen noch mehrere andere Beobachtungen desselben (siehe die Bemerkungen in A. N. 2754). $\mathrm{Zu}$ den von Holden (Monthly Not. Vol. 36 p. 6I) zusammengestellten Daten über die Sichtbarkeit dieses Sternchens ist noch hinzuzufügen, dass Prof. Young und Schimpff mit dem 23 zöll. Refractor der Sternwarte zu Princeton im August i 884 ebenfalls nahe beim Centrum ein äusserst schwaches Sternchen durch die Nebelmasse schimmern sahen (Sirius Bd. XVIII pag. 142 ).

Nach einer mündlichen Mittheilung hat Prof. Young in Gemeinschaft mit Barnard das Sternchen auch im vorigen Jahre gesehen und wird derselbe gewiss nähere Daten hieriiber bekannt geben.

R. Spitaler. 